\section{Analisis SWOT Pada Strategi Pemasaran Produk Simpanan Kurban Di K SPPS BMT N U Sejahtera Cabang Jepara}

\author{
M uyassarah \\ FEBI UIN Walisongo Semarang
}

\begin{abstract}
Purpose- The purpose of this research is to introduce the product to the people of Jepara to participate in the "kurban" saving product at BMT NU Sejahtera through SWOT Analysis

Methods- This study uses qualitative methods and applies analytical techniques from various theoretical references and field data to be analyzed and then concludes logically and critically. The data obtained with the approach of observation, interviews and documentation. Findings- BMT NU who need to pay attention to strategies to approach customers, networks and excellent service. BMT NU Jepara also applies marketing mix or marketing mix / product, price, place, promotion.

Research implications- Research results can be implemented in all BMT institutions in general and specifically for BMT NU Sejahtera
\end{abstract}

Keywords: Analisis SWOT, Strategi Pemasaran, Simpanan Kkurban Dan BM T

\begin{abstract}
Abstrak
Tujuan- Tujuan dari penelitian ini adalah untuk memperkenalkan produk kepada masyarakat Jepara untuk berpartisipasi dalam produk tabungan "kurban" di BMT NU Sejahtera melalui Analisis SWOT Metode- Penelitian ini menggunakan metode kualitatif dan menerapkan teknik analisis dari berbagai referensi teoritis dan data lapangan untuk dianalisis dan kemudian menyimpulkan secara logis dan kritis. Data diperoleh dengan pendekatan observasi, wawancara dan dokumentasi. Hasil- BMT NU yang perlu memperhatikan strategi untuk mendekati pelanggan, jaringan dan layanan prima. BMT NU Jepara juga menerapkan bauran pemasaran atau bauran pemasaran / produk, harga, tempat, promosi.

Implikasi- Hasil penelitian dapat diimplementasikan di semua lembaga BMT secara umum dan khusus untuk BMT NU Sejahtera
\end{abstract}

Keywords: Analisis SWOT, Strategi Pemasaran, Simpanan Kkurban Dan BM T

\section{Pedoman Sitasi}

Muyassarah (2019). Analisis SWOT Pada Strategi Pemasaran Produk Simpanan Kurban Di KSPPS BMT NU Sejahtera Cabang Jepara. SERAMBI, 1(3), 69-80

D 0I: https:/ / doi.org/ 10.36407/ serambi.v1i3.72

\section{SERAM BI}

Received 09Aug 2019

Revised 14 Oct 2019

Accepted 08 Nov 2019

Online first: $18 \mathrm{Nov}$

2019

\section{Paper type}

Research paper

Email

korespondensi:

muyassarah@walisongo .ac.id

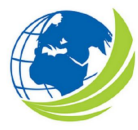

SERAMBI, Vol 1, No.3, 2019, pp. $69-80$

eISSN2685-9904 


\section{Pendahuluan}

Indonesia memiliki jumlah penduduk mayoritas agama Islam, dengan mayoritas muslim mempraktekan sistem perbankan maupun sistem perekonomian berharap menerapkan sistem berbasis nilai-nilai dan prinsip syariah (Islamic economic system) dalam segala bentuk bisnis maupun transaksi kehidupan (Antonio, 2001). Mayoritas umat Islam menganggap bahwa Muamalah Syariah dengan sistem lembaga keuangan yang berlandaskan prinsip syariah bisa menghasilkan kegiatan ekonomi yang lebih adil dan transparan (Widagdo, 2011),sehingga persepsi masyarakat mengenai negative spread dapat dihilangkan seiring dengan perkembangan dan kemajuan lembaga keuangan syariah misalnya bank syariah, asuransi syariah, pasar modal syariah, pegadaian syariah dan KJKS (Koperasi Jasa Keuangan Syariah). Banyaknya Baitul Mal Wat Tamwil (BMT) di masyarakat belum mampu menjawab permasalahan yang dihadapi oleh pelaku usaha mikro maupun masyarakat, terhambat dengan kebutuhan modal. Tambahan dana dibutuhkan oleh UMKM untuk berlangsungnya usahanya, maka masyarakat berharap memberikan kemudahan dalam memberikan bantuan dana ke masyarakat.

Perkembangan BMT di Indonesia banyak kendala dan hambatan yang dihadapi. Misalnya masalah landasan hukum. Karena sebagian BMT memiliki badan hukum koperasi, maka dari itu secara legal tidak dapat menghimpun dana dari masyarakat langsung. Oleh karena itu BMT membuat legalitas dengan cara mensyaratkan keanggotaan bagi nasabah yang akan dilayani, atau menjadikan nasabah tersebut sebagai calon anggota. Dengan sistem perkoperasian sebetulnya bisa direspon dengan positif artinya bisa memanfaatkan sifat fleksi bilitas BMT untuk mengembangkan produknya. Adapun kelebihan BMT dengan lembaga keuangan perbankan antara lain:

1. Fungsi sosial dan fungsi ekonomi, BMT bisa berfungsi membantu masyarakat dan sekaligus bisa melakukan funding dan financing.

2. Sifat fleksibel artinya BMT tidak berbadan hokum bank, sehingga tidak tunduk dibawah aturanaturan perbankan yang ketat, sehingga mudah untuk menyesuaikan kebutuhan masyarakat.

3. SDM BMT berkreatifitas untuk mengembangkan lembaga bertindak aktif, dinamis, proaktif melalui jembut bola nasabah/ anggota.

4. BMT merupakan lembaga mikro yang Islami, sehingga segala aktifitasnya sangat penting untuk mendukung kegiatan dengan prinsip-prinsip Islam, sehingga lambat laun prinsip-prinsip ekonomi Islam dapat dibumikan disemua aspek kehidupan ekonomi.

Dalam Undang-undang nomor 25 tahun 1992 tentang Perkoperasian menjelaskan bahwa permodalan dan pembinaan Koperasi sehingga dapat lebih menjamin kehidupan koperasi dan diperkuat dengan Undang-undang pasal 17 tahun 2012 sebagaimana diamanatkan oleh pasal 33 Undang-undang Dasar 1945 (Menteri Negara Koperasi dan Usaha Kecil dan Menengah, 2007). Dengan dikeluarkannya peraturan pemerintah nomor 9 tahun 1995 tentang pelaksanaan kegiatan usaha simpan pinjam oleh Koperasi serta Kepmen Koperasi dan UKM No 91/ Kep/MKUKM/X/ 2004 tentang petunjuk pelaksanaan kegiatan usaha KJKS maka dengan adanya regulasi tersebut diatas jelas bahwa kegiatan lembaga keuangan Syariah non bank didorong untuk lebih maju dan berkembang lebih baik kedepannya dengan prinsip Islam bahkan mempraktekan prinsip syariah dan mengantisipasi serta mempersiapkan lebiha baik lagi(Antonio, 2001). Dengan aturan tersebut BMT meresponya denga mengembangkan produknya.

Salah satu produk yang ada di BMT NU Sejahtera yakni simpanan kurban/ SIKUR. Tapi banyak masyarakat yang tidak minat dengan jenis simpanan ini, mayoritas Jepara banyak umat muslim menjalankan ibadah kurban setiap hari raya Idul Adha dengan berbagi dengan kaum duafa di sekitar masyarakat Jepara. Strategi pemasaran sangat dibutuhkan, jika BMT NU Sejahtera masih bertindak pasif, maka kemungkinan produk SIKUR ini tidak akan dikenal oleh masyarakat. Strategi yang tepat bisa berdampak pada percepatan proses pertukaran produk kepada masyarakat/ nasabah. 
Karena kegiatan tersebut juga tidak mudah, mengingat persaingan yang dihadapi di pasar, sehingga BMT NU Sejahtera memiliki kreatif dan invatif bergerak cepat dengan menetapkan strategi yang sesuai dengan SWOT (Strenght, Weakness, Opportunities, Threats) untuk bisa tetap bertahan bahkan berkembanga pesat dan mampu bersaing dengan lembaga bank maupun lembaga non bank.

Adapaun penelitian dahulu, (Hidayat \& Rahmat, 2018)menjelaskan faktor yang menjadi kekuatan dan kelemahan, faktor faktor yang menjadi peluang dan ancaman, mengetahui bagaimana posisi bisnis server pulsa CV Star Pratama dibandingkandengan bisnis server pulsa lainnya serta strategi yang harus diterapkan oleh bisnis server pulsa CV Star Pratama.

(TIWI, 2017)menjelaskan bahwa dalam meningkatkan nasabahnya dengan cara mendatangi atau menjemput, servis ramah, pencairan dana dan pembiayaan mudah sedangkan startegi pemasaran $4 \mathrm{P}$ belum menerapkan secara keseluruhan. (Firmansyah \& Abdilah, 2014)menjelaskan Strategi pemasaran khususnya pemasaran produk pembiayaan yangditerapkan oleh PT. Panin Bank Syariah, Tbk. Kantor Cabang Malang meliputi beberapa strategi, yakni strategi jemput bola, referal, membangun jaringan, memberikan servise excellent, dan memberikan fasilitas yang memuaskan untuk meningkatkan kepercayaan dan kepuasan nasabah, sehingga nasabah yang ada tidak akan lari dari bank. (b) Hasil analisis SWOT menyebutkan bahwa PT. Panin Bank Syariah, Tbk. Kantor Cabang Malang sudah bisa bersaing di pasar persaingan yang kompetitif yang ada di wilayah Malang.

Adapun persamaan penelitian ini dengan penelitian sebelumnya yakni sama-sama mengkaji BMT dan pemasaran produk-produknya dan strategi pemasaran BMT sama yakni pendekatan dengan mendatangi mudharib/ nasabah, adapun perbedaan penelitian ini sangat komprehensif dan penting untuk difokuskan karena Indonesia menjadikan lembaga keuangan syariah non bank merupakan lembaga yang mampu mendongkrak UMKM yang semakin maju dan meningkatkan berdirinya UMKM baru, karena UMKM di Indonesia dapat mendorong dan meningkatkan pertumbuhan ekonomi. Adapun obyek penelitian adalah BMT NU Sejahtera Jeparadan jenis produk yang akan di pasarkan yakni produk SIKUR / simpanan kurban. Strategi pemasaran dalam penelitian ini marketing mix, berbagai promosi penjualan produk simpanan kurban, selain itu juga menggunakan pendekatan mendatangi mudharib/ nasabah, network dan services excellen. Sehingga tujuan penelitian ini untuk mengetahui strategi pemasaran produk SIKUR BMT NU Sejahtera yang diananlisa dengan pendekatan SWOT.

\section{Kajian Teori \\ Analisis SWOT}

Analisis SWOT merupakan analisis untuk mengetahui kekuatan dan kelemahan, peluang maupun tantangan yang ada dalam strategi pemasaran BMT NU Sejahtera yang terdiri Strenght (kekuatan), Weakness (kelemahan), Opportunities (peluang), dan Threats (ancaman). Pendekatan SWOT untuk menyususn strategi baik di lembaga keuangan maupun suatu perusahaan/ organisasi. Berikut ini analisis SWOT yang digunakan dalam perbankan(Rangkuti, 2006) :

Strenght (kekuatan)

Kekuatan merupakan suatu keunggulan dalam sumber daya, ketrampilan dan kemampuan lainnya yang relatif terhadap pesaing dan kebutuhan pasar yang dilayani oleh perusahaan atau lembaga. Misalnya dalam hal teknologi yang dimiliki, letakkantor cabang yang berada di setiap kabupaten, mitra kerjasama nasional.

W eakness (kelemahan)

Kelemahan dalam suatu lembaga atau perusahaan berupa sumber daya, ketrampilan dan kemampuan yang secara serius menghalangi kinerja efektif suatu lembaga atau perusahaan(Fahmi, 2014).Misalnya kinerja atau etos kerja karyawan, cost promosi, belum terpenuhinya kesehatanatau belum memenuhi standar dari lembaga keuangan atau perusahaan tersebut. 
Opportunities (peluang)

Peluang merupakan suatu situasi utama yang menguntungkan dalam lingkungan BMT atau perusahaan, misalnya regulasi kebijakan yang dikeluarkan pemerintah, tingkat pertumbuhan ekonomi yang relatif tinggi dan sebagainya.

Threats (Ancaman)

Ancaman merupakan situasi utama yang tidak menguntungkan dalam lingkungan BMT atau perusahaan. Sebagai contoh yakni berkembangnya pasar modal.

Dari penjelasan di atas dapat disimpulkan bahwa analisis SWOT merupakan cara untuk merencanakan strategis yang digunakan untuk mengevaluasi Strenght (kekuatan), Weakness (kelemahan), O pportunities (peluang), dan Threats (ancaman) dalam suatu BMT NU Sejahtera. Cara analisa SWOT untuk melihat faktor internal dan eksternal yang terlibat sebagai masukan dalam rangka merencanakan proses. Sehingga proses yang sudah direncanakan dapat berjalan optimal, efektif dan efesien sesuai dengan harapan BMT NU Sejahtera.

Kondisi kinerja BMT NU Sejahtera ditentukan oleh kombinasi faktor internal dan eksternal. Kedua faktor itu dipertimbangkan dalam analisis SWOT yang membandingkan antara faktor internal (kekuatan dan kelemahan) dan faktor eksternal (peluang dan ancaman). Oleh karena itu proses perencanaan, menentukan tujuan, sasaran dan strategi-strategi yang akan dipraktekkan oleh BMT NU Sejahtera harus jitu dan pengintegrasian antara faktor internal dan eksternal, di perlukan suatu analisis mendalam secara komprehensip mengenai lingkungan dimana lembaga keuangan syariah berada, tahapan proses perencanaan awal hingga akhir perlu di evaluasi setelah sudah dilaksankan programnya.

\section{Analisis dengan Matrix SWOT}

Analisis matrik SWOT dapat menggambarkan secara jelas bagaimana peluang dan ancaman sebagai faktor eksternal dapat disesuaikan dengan kekuatan dan peluang sebagai internal yang dimiliki oleh lembaga keuangan Syariah(Hendri Tanjung dan Didin Hafidhudin, 2019). Oleh karena itu factor eksternal dan internal perlu di jabarkan, agar mendapatkan hasil yang bisa dijual di masyarakat.

Tabel Metrik Analisa Swot

\begin{tabular}{|l|l|l|}
\hline & $\begin{array}{l}\text { Strenght (S) } \\
\text { Daftar semua kekuatan yang } \\
\text { dimiliki }\end{array}$ & $\begin{array}{l}\text { Weakness (W) } \\
\text { Daftar semua kelemahan yang } \\
\text { dimiliki }\end{array}$ \\
\hline $\begin{array}{l}\text { Opportunities (O) } \\
\text { Daftar semua peluang } \\
\text { yang dapat diidentifikasi }\end{array}$ & $\begin{array}{l}\text { Strategi SO } \\
\text { Terapkan semua kekuatan yang } \\
\text { dimiliki untuk memanfaatkan } \\
\text { peluang yang ada }\end{array}$ & $\begin{array}{l}\text { Strategi WO } \\
\text { Berantas semua kelemahan } \\
\text { dengan memanfaatkan semua } \\
\text { peluang yang ada }\end{array}$ \\
\hline $\begin{array}{l}\text { Threats (T) } \\
\text { Daftar semua ancaman } \\
\text { yang dapat diidentifikasi }\end{array}$ & $\begin{array}{l}\text { Strategi ST } \\
\text { Menerapkan semua kekuatan } \\
\text { dan kelebihan untuk } \\
\text { menghindar mencegah adanya } \\
\text { berbagai ancaman }\end{array}$ & $\begin{array}{l}\text { Strategi WT } \\
\text { Meminimalkan } \\
\text { kelemahan dan cegah semua } \\
\text { ancaman }\end{array}$ \\
\hline
\end{tabular}

Konsep SWOT merupakan suatu analisis yang diterapkan secara berkesinambungan yang saling berhubungan antara keempat komponen untuk mencapai tujuan yang sudah ditargetkan oleh BMT NU Sejahtera Seperti pada strategi SO. Strategi yang bersifat agresif, agar tercapai tujuan BMT NU 
Sejahtera. Strategi WO didapat ketika manejemen berusaha memanfaatkan peluang bisnis yang tersedia untuk mengurangi bahkan mengeliminasi kelemahan BMT NU Sejahtera. Strategi ST serupa dengan strategi WO kedua variabel yang ada tidak maksimal, karena strategi ST lahir dari analisis manajemen yang hendak menggunakan kekuatan dan keunggulan yang dimiliki untuk menghindari efek negatif dari ancaman bisnis yang dihadapi. Strategi WT pada dasarnya mengutamakan strategi untuk bertahan artinya strategi bisnis yang masih mungkin ditemukan dan dipilih dengan meminimalisasi kelemahan dan menghindari ancaman BMT NU Sejahtera(Ahmad Hasan Ridwan, 2015)

Matrix SWOT dapat menggambarkan bagaimana peluang dan ancaman dari lingkungan eksternal BMT NU Sejahtera diantisipasi dengan kekuatan dan kelemahan yang dimilikinya. Matrix ini dapat menghasilkan empat set adalah (Rangkuti, 2006)

Strategi SO (Strenght-opportunity)

Strategi merupakan jalan keluar BMT NU Sejahtera dengan memanfatkan seluruh kekuatan yang dimiliki untuk merebut dan memanfaatkan peluang sebesar-besarnya.

Strategi ST (Strenght-Threats)

Strategi merupakan kekuatan-kekuatan yang dimiliki BMT NU Sejahtera untuk mengantisipasi ancaman-ancaman yang ada. Sebetulnya keberadaan perempuan-perempuan sebagai bendahara keluarga dapat dijadikan sumber kekuatan lembaga keuangan di Indonesia (Nurudin \& Muyassarah, 2017)

Strategi WO (W eakness-O pportunity)

Strategi merupakan pemanfaatan peluang yang ada dengan cara memi nimalkan kelemahan yang ada di BMT NU Sejahtera. Peluang yang diciptakan BMT dengan cara menggali potensi budaya / tradisi misalnya walimatul ursy, walimatul kitan dan lain-lain yang merupakan peluang untuk diprospek BMT (Muyassarah, 2016).

Strategi WT (W eakness-Threath)

Strategi merupakan aktifitas yang bersifat defensif, berusaha meminimalkan kelemahan-kelemahan BMT NU Sejahtera serta sekaligus menghindari ancaman-ancaman yang menyelimutinya.

\section{Baitul M aal Wat Tamwil}

Baitul M aal Wat Tamwiil disebut BMT, segi Bahasa adalah rumah uang dan pembiayaan, Baitul M aal adalah rumah uang. Baitul $M$ aal adalah lembaga keuangan berorientasi sosial keagamaan yang kegiatan utamanya menampung serta menyalurkan harta masyarakat berupa zakat, infaq, shadaqah (ZIS) berdasarkan ketentuan yang telah ditetapkan Alqur'an dan Sunnah Rasul-Nya. Karena berorientasi sosial keagamaan, prinsip-prinsip Islam tidak bisa dimanipulasi untuk kepentingan bisnis atau mencari laba (profit).

BMT di era industry 4.0 lebih menekankan pada formulasi strategi yakni aktifitas yang berhubungan dengan hal-hal pencapian tujuan yang sudah ditargetkan. Misalnya dimulai dalam mempersiapkan strategi, pemilihan strategi, menetapkan strategi yang akan digunakan, mengidentifikasi ancaman dan peluang serta menetukan kekuatan dan kelemahan BMT dalam rangka untuk mencapai tujuan jangka panjang.

Implementasi strategi merupakan cara mengoprasionalkan atau melaksanakan strategi dalam BMT. Strategi yang telah diformulasikan dalam BMT diimplementasikan. Perbedaan utama antara formulasi strategidanimplementasi strategi sejalan dengan perbandingan antara isi dengan proses.Tahap formulasi strategi menentukan isi strategi, sedangkan tahapimplementasi strategi 
berfokus pada bagaimana strategi dicapai.Implementasistrategi mensyaratkan BMT untuk menetapkan tujuan tahunan,menetapkan kebijakan, mengalokasikan sumber daya, mengubah strukturorganisasi yang ada, restrukturisasi dan desain ulang, merevisi rencana insentifdan pemberian imbalan kepada karyawan, meminimalkan resistensi terhadapperubahan, mengembangkan budaya yang mendukung strategi,mengadaptasikan proses produksi atau operasi, mengembangkan fungsi sumberdaya manusia yang efektif.

Setelah dilakukan langkah strategi isi dan proses kemudian langkah terakir strategi evaluasi faktor internal maupun eksternal, strategi evaluasi merupakan strategi evaluasi yang berhubungan dengan penilaian dampak keseluruhan dan ketepatanstrategi secara keseluruhan. Strategi evaluasi selalu dilakukan setiap selesainya kegiatan minimalkan pada akhir tahun sebagai tutup buku dalam suatu perusahaan atau lembaga keuangan.

BMT NU Sejahtera merupakan lembaga keuangan yang ada di daerah Jepara yang memiliki produk simpanan kurban/ SIKUR agar masyarakat sekitar Jepara memanfaatkan produk tersebut. Adapun cara yang digunakan BMT NU Sejahtera menerapkan berbagai media promosi dan sasarannya adalah masyarakat Jepara muslim yang merencanakan berkurban maupun lembaga pemerintah/ swasta yang memiliki perhatian besar untuk meningkatkan interpersonal dalam memahami Islam melalui berkurban. BMT NU Sejahtera sebagai lembaga keuangan yang menerapkan prinsip-prinsip syariah , tentu saja BMT ini membutuhkan strategi pemasaran produk SIKUR yang afektif dan efisien untuk mendapatkan mudharib dan menghadapi persaingan dengan para competitor pendatang baru.

\section{Metode Penelitian}

\section{Desain Pemikiran}

Produk Simpanan Kurban/SIKUR merupakan produknya BMT NU Sejahtera Jepara yang menerapkan prinsip-prinsip syariah. Lingkungan internal merupakam lembaga BMT NU Sejahtera yang menunjukkan kekuatan dan kelemahan. Dasar analisis yangdigunakan untuk lingkungan internal berdasarkan analisis STP(Segmentation, Targetting, dan Positioning) dan bauran pemasaran.Sedangkan untuk lingkungan eksternal menunjukan suatu kondisi berupapeluang dan ancaman di luar lembaga. Lingkungan eksternal terdiri dari masyarakat dan BMT lain.Perumusan strategi pemasaran untuk mencapai tujuan yang diinginkandiawali dengan melakukan analisis STP (Segmentation, Targetting, danPositioning) dan identifikasi bauran pemasaran yang terdiri dari 4P, yaituproduct, price, place, promotion.Setelah melakukan analisis STP dan bauran pemasaran, kemudiandilakukan proses identifikasi faktor-faktor yang mempengaruhi penyusunanstrategi pemasaran produk SIKUR BMT NU Sejahtera.Tahapan selanjutnya yaitu memasukan faktor-faktor yang berasal darilingkungan internal ke dalam matriks IFE (Internal Factor Evaluation) danfaktorfaktor yang berasal dari lingkungan eksternal ke dalam matriks EFE(External Factor Evaluation).Hasil yang diperoleh dari faktor internal dan eksternal BMT NU Sejahtera dijadikan dasar untuk kemudian dianalisis dengan menggunakan matriksSWOT (Strenghts, Weaknesses, Opportunities, Threats), sehingga diperolehbeberapa alternatif strategi pemasaran. Hasil dari faktor internal dan eksternal juga digunakan dalam analisis matriks IE (Internal External), tujuannya untukmendapatkan strategi pemasaran yang lebih detail.Terakhir, yaitu tahap pengambilan keputusan untuk memilih strategi pemasaran terbaik yang telah dihasilkan dari perpaduan matriks SWOT dan matriks IE, strategi yang dikembangkan oleh BMT NU Sejahtera Jepara.

\section{Populasi dan Sampel}

Penelitian ini dilaksakan di lembaga keuangan non bank Pembelajaran yakni BMT NU Sejahtera Jepara. Data yang digunakan dalam penelitian ini adalah data primer dan datasekunder. Data primer diperoleh melalui wawancara yakni manajer lapangan dan karyawanWawancara yang dilakukan 
mengenai hal-hal yang terkait dengantujuan penelitian). Data sekunder diperoleh dari studi pustaka, data-data yangdimiliki BMT NU Sejahtera Jepara dan artikel dari website yang terkait denganpenelitian.

\section{Teknik pengambilan sampel dan $t$ analisis}

Pengolahan Data

Analisis dalam penelitian ini dimulai dengan mengidentifikasifaktor-faktor lingkungan internal dan eksternal BMT NU Sejahtera. Datadan informasi yang diperoleh dari lingkungan internal berupa segmentasi,target pasar, dan posisi pasar serta bauran pemasaran yang dianalisissecara kualitatif untuk mengetahui kekuatan dan kelemahan yang dimilikilembaga. Sama halnya dengan data dan informasi yang diperoleh darilingkungan eksternal lembaga mengenai lingkungan jauh dan lingkunganindustri, diklasifikasikan secara kualitatif untuk mengetahui peluang danancaman yang dihadapi lembaga.

\section{A nalisis Data}

Setelah mengolah dan menganalisis lingkungan internal daneksternal lembaga, maka dapat dilakukan tahap selanjutnya denganmerumuskan strategi melalui tiga tahapan. Tahap pertama adalah tahapmasukan dengan menggunakan IFE (Internal Factor Evaluation) matriksuntuk mengidentifikasi faktor-faktor yang menjadi kekuatan dankelemahan yang dimiliki Lembaga serta EFE (External FactorEvaluation) matriks untuk mengidentifikasi faktor-faktor yang menjadipeluang dan ancaman yang dihadapi lembaga. Tahap kedua adalahpencocokan dengan menggunakan matriks IE (Internal External) danmatriks SWOT (Strenghts-Weaknesses-Opportunities-Threats).Matriks IE digunakan untuk memperoleh strategi bisnis yang lebihdetail dan matriks SWOT digunakan untuk memperoleh alternative alternatif strategi pemasaran yang sesuai bagi lembaga berdasarkankekuatan, kelemahan, peluang, dan ancaman yang dihadapi lembaga.Tahap terakhir adalah tahap pengambilan keputusan untuk memantapkan dan komitmen menentukan dan memilih strategi pemasaran yang terbaik dan tepat bagi BMT NU Sejahtera.

Factor Evalution)Matriks IFE (Internal Factor Evaluation) merupakan alatperumusan strategi yang digunakan untuk mengetahui faktor-faktorinternal lembaga berkaitan dengan kekuatan dan kelemahan yang dianggappenting. Data dan informasi aspek internal lembaga dapat diperoleh daribeberapa fungsional lembaga, sistem informasi, dan produksi operasi.Faktor-faktor internal yang dianalisis adalah segmentation, targetting, danpositioning serta bauran pemasaran yang terdiri dari product, price, place,promotion. Data yang diperoleh dari analisis lingkungan internal berupakekuatan dan kelemahan dan anal isis lingkungan eksternal berupa peluangdan ancaman yang dihadapi oleh lembaga, kemudian didaftar dandievaluasi.

Setelah melalui tahap analisis faktor-faktor internal, selanjutnya adalah melakukan analisis faktor-faktor eksternal, digunakan untuk menganalisis faktor-faktor eksternal yang menjadipeluang dan ancaman bagi lembaga, baik berpengaruh secaralangsung maupun tidak langsung. Faktor eksternal lembaga yangakan dianalisis yaitu lingkungan masyarakatdan lingkungan BMT lain/ kompetitor baru.Analisis SWOT adalah identifikasi berbagaifaktor secara sistematis untuk merumuskan strategi lembaga. Analisisini didasarkan pada logika yang dapat memaksimalkan strengths(kekuatan) dan opportunities (peluang), namun secara bersamaan dapatmeminimalkan weaknesses (kelemahan) dan threats (ancaman). Prosespengambilan keputusan strategis selalu berkaitan denganpengembangan misi, tujuan, strategi, dan kebijakan lembaga. AnalisisSWOT membandingkan antara faktor eksternal yaitu peluang danancaman dengan faktor internal berupa kekuatan dan kelemahan,sehingga analisis tersebut dapat diambil suatu keputusan strategi BMT NU Sejahtera.Swot menentukan key success factors untuk lingkungan eksternal daninternal merupakan 
bagian yang sulit sehingga dibutuhkan judgmentyang baik. Sementara itu, tidak satu pun matching tool yang dianggappaling baik .

\section{Hasil dan Diskusi}

\section{Penerapan Analisa SWOT dalam Strategi Pemasaran}

Penerapan analisis SWOT pada streategi pemasaran diproduk simpanan kurban dilakukan dengan melihat langkah-langkah pokok proses perencanaan, perencanaan yang diterapkan mulai dari tujuan, sasaran jangka pendek dan panjang, kemudian merencanakan strategi dan program, serta koordinasi dengan kepala bagian-bagian devisi bahkan diakhiri dengan evaluasi kembali mana yang dianggap sebagai kendala tidak tercapainya tujuan. Setelah di analisa dengan pendekatan SWOT situasi kegiatan BMT NU Sejahtera kemudian langkah selanjutnya strategi pemasaran disusun untuk mencapai tujuan yang sudah ditargetkan dalam jangka panjang.

Analisis SWOT ini sangat penting untuk dilakukan karena dari hasil analisis, BMT NU Sejahtera meninjau kembali kekuatan, kelemahan, peluang dan ancaman yang akan dihadapi oleh BMT NU Sejahtera dan juga jurus strategi apa yang harus dilakukan untuk menghadapi persaingan pasar (Rangkuti, 2015). Sehingga dalam hal ini BMT terus eksis dalam menjalankan funding maupun financing melalui beberapa produk yang akan ditawarkan di pasar dengan pesaing-pesaing yang sangat kompetetif. Penerapan analisis SWOT dalam strategi pemasaran ini merupakan langkahlangkah konkrit dalam melakukan evaluasi dalam rangka untuk mengembangkan dan tetap eksisnya BMT NU Sejahtera.

Jika kekuatan dan peluangnya lebih besar atau lebih kuat dibandingkan dengan kelemahan dan ancaman yang akan dihadapi, BMT NU Sejahtera tidak perlu melakukan konsolidasi begitu juga sebaliknya, jika kekuatan dan peluangnya lebih kecil, maka BMT NU Sejahtera harus melakukan konsolidasi untuk mempertahankan kelangsungan hidupnya. Tapi BMT NU Sejahtera dalam kondisi apapun setiap bulannya tetap melakukan evaluasi diri karena persaingan lembaga keuangan syariah semakin ketat dan ramai.

\section{SIKUR /Simpanan Kurban}

Simpanan kurban/SIKURmerupakan produk simpanan yang bertujuan untuk mempersiapkan nasabah/ anggota BMT NU Sejahtera untuk ikut serta menjalankan ibadah kurban pada saat hari raya Idul Adha. Adapun besarnya setoran disesuaikan dengan harga hewan korban baik kambing maupun sapi. Simpanan kurban/ SIKUR diambil 2 minggu sebelum hari raya Idul Adha, sedangkan bagi hasil akan di dapat setiap bulan sesuai dengan saldo rata-rata. BMT NU Sejahtera produk simpanan kurban menggunakan akad Mudharabah, nasabah/ anggota berniat menjalankan ibadah kurban dengan iklas, maka BMT NU Sejahtera membantu memberikan fasilitas pengadaan serta penyaluran hewan kurban sesuai dengan akadnya. Adapun prosedur syarat dan ketentuan:

1. Jumlah simpanan minimal sesuaikan kemampuan nasabah dan jangka waktu maupun jenis hewan kurban

2. Tidak ada biaya administrasi

3. Nisbah bagi hasilnya: Investor: $30 \%$, BMT NU Sejahtera :70\%

4. Penarikan untuk kurban

Tabel 1. Tabulasi Investasi Kurban

\begin{tabular}{|l|l|l|l|}
\hline No & Harga Hewan & Setoran/ Bulan & Jangka Waktu \\
\hline 1 & KAMBING & & \\
& 1EKOR @2.500.000 & Rp 210.000 & 12 Bulan \\
& 1EKOR @2.700.000 & Rp 225.000 & 12 Bulan \\
& 1EKOR @3.500.000 & Rp 292.000 & 12 Bulan \\
\hline
\end{tabular}




\begin{tabular}{|l|l|l|l|}
\hline 2 & SAPI & Rp 250.000 & 12 Bulan \\
& 1EKOR @21.000.000 & Rp 310.000 & 12 Bulan \\
& 1EKOR @25.000.000 & Rp 350.000 & 12 Bulan \\
\hline
\end{tabular}

Keterangan :.Panduan tabulasi investasi kurban tahun 2019 dan waktu dan jumlah setoran sesuai harga hewan kurban, hewan kurban sapi secara kolektif atau kelompok yang terdiri 7 orang.

Tahapan strategi harus dilakukan oleh BMT agar tercapai tujuan yang sudah ditetapkan. BMT NU Sejahtera Jepara kegiatan pemasaran untuk menjual produk dilakukan secara sinergis, dan terintegrasi, untuk mengkoordinasikan dengan kemampuan BMT dengan tantangan lingkungan untuk mencapai tujuan akhir. Tidak hanya strategi yang dijalankan namun pemasaran juga dijalankan karena pemasaran bagi BMT merupakan suatu kebutuhan yang harus dijalankan, karena untuk menghadapi perkembangan pasar dan persaingan pasar yang semakin ketat, membuat sebuah lembaga dituntut agar bisa menyusun strategi pemasaran sesuai dengan visi misi BMT.

Strategi pemasaran suatu hal utama dan penting bagi BMT NU Sejahtera agar tujuan yang direncanakan dapat berjalan sesuai dengan harapan dan mampu mengatasi hambatan dan kendala yang ada. Setelah dilakukan penelitian dan wawancara dengan Kabag manajer BMT NU Sejahtera, strategi pemasaran yang dijalankan ada tiga strategi untuk mendapatkan nasabah:

Strategi jemput bola

Strategi jemput bola adalah pihak BMT NU Sejahtera mendatangi nasabah yang dianggap potensial untuk bisa gabung dan minat dengan produk simpanan kurban. Calon nasabah yang potensial tersebut didatangi dengan cara persuasif dan berdakwah. Pihak BMT menjaga hubungan kekuluargaan dam memberikan keyakinan syariah agar nasabah percaya terhadap BMT NU Sejahtera.

Strategi ini dilakukan oleh marketing BMT NU Sejahtera mengingat masih banyak masyarakat Jepara masih awam belum mengenal produk simpanan kurban. Agar mendapatkan nasabah BMT NU Sejahtera melakukan strategi jemput bola yaitu. BMT selalu berusaha dengan segenap kemampuan dan strategi yang dimiliki sampai pada akhirnya calon nasabah tersebut bersedia menjadi nsabah produk simpanan kurban. Meskipun begitu, BMT harus tetap menjaga rasa kekeluargaan tersebut agar nasabah percaya dan yakin bahwa bermitra dengan BMT NU Sejahtera benar adanya. Maka nasabah akan mendapatkan kenyaman dan nasabah abadi terhadap BMT NU Sejahtera jika dijalin hubungan familier antara nasabah dengan pihak BMT.

\section{Membuat N etwork}

Strategi network adalah pihak BMT NU Sejahtera mampu meningkatkan hubungan atau relasi dari berbagai pihak baik perorangan, perusahaan maupun pihak pemerintahan baik dalam kota maupun luar kota yang lebih luas. Dengan menjaring network, maka produk-produk BMT NU Sejahtera akan di cari oleh pengguna yakni masyarakat luas.

Service Excellent

Strategi service excellent adalah layanan prima, cepat, tepat sesuai apa yang menjadi keinginan semuanasabah. Pihak BMT NU telah melakukan strategi pada setiap nasabah agar produk BMT NU Sejahtera terjual ke nasabah terutama produk SIKUR , karena menghadapi berbagai karakter nasabah, maka pihak BMT NU Sejahtera tetap sabar, ramah, iklas dan memberikan pencerahan kepada nasabah dengan pendekatan dakwah. Service excellent ini merupakan salah satu nilai lebih diprioritaskan agar kepuasan dan kepercayaan nasabah semakin meningkat. 
BMT NU Sejahtera dalam rangka untuk mencapai harapan berbagai pihak, tidak hanya menerapkan tiga strategi diatas, namun juga menerapkan marketing mix dari product, price, place, promotion, yaitu :

Strategi Product

Strategi produk adalah cirikas produk yang dimiliki BMT NU Sejahtera, dimana strategi produk yang menitikberatkan pada brand, logo dengan tujuan agar nasabah selalu teringat di hati. Agar nasabah tidak kecewa diakhir akad, maka perlu adanya strategi produk dipaparkan kel ebihan dan kekurangan produknya. Produk SIKUR disampaikan angsuran yang ringan dan nisbah bagi hasil nasabah dan BMT 30\%:70\%. Adapun sistem teknik pembayaran fleksibilitas artinya bisa dilakukan dengan sistem jemput bola yang berorientasi agar pihak nasabah merasa nyaman dan senang bermitra dengan pihak BMT NU Sejahtera.

Strategi Price/ harga

Strategi harga adalah cara menawarkan produk dengan harga yang murah dan ringan bagi nasabah agar produk SIKUR dapatdiminati dan nasabah lain beralih ke produk yang ditawarkan oleh BMT NU Sejahtera. Dengan strategi harga ini pihak BMT NU Sejahtera menyesuaikan harga hewan dan memberikan nisbah bagi hasil atau bonus yang berharga. Perbedaan harg disesuaikan karakteristik dan tujuan masing-masing produk BMT NU Sejahtera. Adapun harga dalam SIKUR disesuaikan dengan perkiraan harga hewan kurban yang menjadikan pilihan nasabah.

Strategi Place/ tempat

Strategi tempat adalah strategi lokasi BMT NU Sejahtera terjangkau nasabah. Oleh karena itu lokasi BMT itu harus terletak strategis dengan tujuan untuk menambahnasabah sebanyak-banyaknya. Nasabah pelanggan di pelihara dan tetap bertambahnya nasabah baru yang menjadi nasabah abadi. Strategi tempat ini merupakan salah satu factor penentu untuk menarik minat nasabah untuk menjadi mitra BMT NU Sejahtera.

Strategi Promotion/ promosi

Strategi promosi adalah upaya atau kiat memberitahukan produk SIKUR kepada nasabah, startegi promosi merupakan peran penting untuk mempengaruhi minat nasabah untuk beli produk. Strategi promosi di BMT NU Sejahtera untuk menginformasikan segala jenis produk yang ditawarkan dan berusaha untuk menarik nasabah baru untuk menjadi nasabah abadi bahkan potensial serta mempertahankan nasabah sebagai pelanggan setia. Adapun promosi yang dilakukan BMT NU Sejahtera antara lain:

Promosi periklanan

Sistem periklanan BMT NU Sejahtera berbentuk brosur baik di kantor pusat dan kantor cabang, promosi melalui kalender, poster yang diberikan nasabah yang bermitra dengan pihak BMT.

Promosi penjualan

Sistem promosi yang dilakukan BMT NU Sejatera melalui pendekatan pemberian cendera mata contohnya paying, kalender, gelas dan lain-lain saat nasabah bermitra dengan pihak BMT. Tujuan promosi ini untuk menarik nasabah dan bertujuan untuk mempertahankan nasabah agar sebagai pelanggan abadi.

Penjualan pribadi

Sistem promosi penjualan pribadi maksudnya pihak karyawan BMT NU Sejahtera mampu menjelaskan segala sesuatunya tentang produk kepadanasabah, selain mnejelaskan produk pihak 
BMT juga menugaskan karyawan untuk bersilaturahmi pada calon-calon nasabah yang dianggap potensial.

BMT NU Sejahtera menganggap bahwa strategi pemasaran penting tetap dipertahankan walaupun persaingan perbankan sekarang sangat ketat. Strategi pemasaran tetap menjunjung tinggi prinsip-prinsip syariah. BMT NU sejahtera menyadari bahwa BMT ini merupakan lembaga keuangan syariah, sehingga proses awal transaksi hingga berakhirnya transasksi jauh dari hal-hal yang dilarang Islam. Selain mengimplementasikan teori marketing, pihak BMT NU Sejahtera mengharapkan pihak shahibul maa/ karyawan tidak hanya menjual saja tetapi mampu meningkatkan target yang diinginkan.

\section{Kesimpulan}

A nalisis SWOT untuk melihat kekuatan, kelemahan, peluang dan ancaman yang akan dihadapai oleh BMT NU Sejahtera. Kekuatan yang dimiliki dan mengembangkan kekuatan itu dapat dipastikan bahwa BMT NU Sejahtera akan lebih maju dibanding dengan lembaga keuangan lain sebagai pesaing yang ada. Begitu juga kelemahan yang dimiliki BMT NU Sejahtera harus diperbaiki agar BMT ini tetap eksis. Peluang yang ada harus dimanfaatkan sebaik-baiknya oleh BMT NU Sejahtera agar produk-produk yang dikeluarkan bisa menjadi pilihan bagi masyarakat dan ancaman yang akan dihadapi oleh BMT NU Sejahtera haruslah dihadapi dengan mengembangkan strategi pemasaran yang baik.

BMT NU Sejahtera selain menerapkan marketing mix dari product, price, place, promotion juga menerapkan strategi lain misalnya pendekatan jemput bola, network, service excellen. BMT NU Sejahtera juga menerapkan periklanan contohnya promosi periklanan, promosi penjualan, promosi melalui penjualan pribadi dalam rangka untuk meninggaktkan nasabah dan BMT NU Sejahtera tetap kerja keras untuk menggali nasabah agar tertarik pada produk simpanan kurban.

Strategi BMT NU Sejahtera dalam pemasaran untuk mempertahankan kelangsungan BMT, dengan tujuan untuk berkembang dan untuk menjaga nasabah agar tetap menjadi nasabah abadi yang selalu diprospek pihak BMT. Proses marketing awalnya ditekankan untuk meningkatkan penjualan. Sehingga tidak hanya menjual namun meningkatkan semakin bertambah jumlah nasabah walaupun dalam persaingan yang tinggi, karena menjamurnya lembaga keuangan syariah.BMT NU Sejahtera menekankan pendekatan familiyer dengan nasabah, sehingga nasabah tidak dianggap pembeli tetapi dianggap saudara, teman maupun keluarga untuk menciptakan hubungan yang akrab dengan nasabah atau mudharib.

\section{D aftar Pustaka}

A hmad Hasan Ridwan. (2015). M anajmen Baitul M al Wa Tamwil (BM T), Pustaka Setia, Jakarta

Almas, B. (2019). Keadilan Redistribusi Perspektif Islam, Jurnal Iqtishoduna ,Vol.8, No. 135-170.

Ansah, A. (2017). pengaruh desain produk, promosi, dan citra merek terhadap keputusan pembelian sepatu nike original pada pelanggan sport station solo.A mwaluna: Jurnal Ekonomi D an Keuangan Syariah,Vol1, N 02, 178-189.

Antonio, M. S. (2001). Bank Syariah dari Teori ke Praktek. Gema Insani, Jakarta

Hendri Tanjung dan Didin Hafidhudin, (2019), Pengantar Manajemen Syariah, RajaGrafindo Persada, Jakarta

Irham Fahmi.(2015) M anajemen Strategis, CV Alfabeta, Bandung

Menteri Negara Koperasi dan Usaha Kecil dan Menengah. (2007). Pedoman Standar Operasional $M$ anajemen Koperasi Jasa Keuangan Syariah dan U nit Jasa Keuangan Syariah Koperasi.

Mokh Syaiful Bakhri. (2015). Sukses Koperasi Syariah Di Sidogiri, Gramedia, Jakarta

Muyassarah, M. (2016). Nilai Budaya Walimah Perkawinan (Walimatul ‘Urusy) Dalam Pemberdayaan Ekonomi Masyarakat (Studi Kasus di Kelurahan Gondorio Ngaliyan Semarang). Jurnal sosial dan studi keagamaan, IN FERE N SI, Vol.10 N 02, 539.

Nurudin, N., \& Muyassarah, M. (2017). Menilik perempuan sebagai social climber dalam pandangan 
ekonomi islam. Sawwa: Jurnal Studi Gender, Vol 12 No 2, 225

Rangkuti, F. (2006). A nalisis SWOT : Teknik M embedah Kasus Bisnis, PT Gramedia Pustaka Utama, Jakarta.

Rianto, N. (2012). D asar-dasar Pemasaran Bank Syariah, . Alfabeta, Bandung:

Stanton, W. J., \& Stanton, W. J. (2006). Prinsip pemasaran jilid I, Er;angga, Jakarta

Sudibyo, T. G. dan U. H. (2011). M arketing M uhammad: Strategi Andal dan Jitu Praktis Bisnis Nabi M uhammad SA W. Madania Prima, Bandung.

Sumarwan, U. (2017). Perilaku Konsumen Teori Dan Penerapanya Dalam Pemasaran. Ghalia Indonesia., Bogor

Widagdo, H. (2011). Analisis Pengaruh Kualitas Layanan Dan Promosi Terhadap Keputusan Konsumen Membeli Komputer Pada PT. XYZ Palembang,Forum Bisnis D an Kewirausahaan Jurnal IImiah STIE M DP, Vol 1 No 1. 1-10.

Ernanda Kusuma Dewi dan Ayu Astari , Peran Pembiayaan Mudharabah Dalam Pengembangan Kinerja Usaha Mikro Pada Bmt (Baitul Maal Wat Tamwil) (2017), Jurnal Law and Justice Vol. 2 No. 2,113-123

\section{About Author}

Muyassarah, Kelahiran Rembang, 29 A pril 2071. Penulis merupakan sekretaris SI Perbankan Syariah di UIN Walisongo Semarang. Penulis mengembangkan karirnya sejak tahun 2000 dengan pengalaman mengajar rumpun matakuliah Ekonomi Islam dan Perbankan Syariah dengan email: muyassarah@walisongo.ac.id

Accepted author version posted online: 18 November 2019

Vika Nurul Mufidah, (Reviewing editor)

$$
\text { (c) (1) }
$$

(c) 2019 The Author(s). This open access article is distributed under a Creative Commons Attribution (CC-BY) 4.0 license 